\title{
Pollen load and distribution on the body of Elaeidobius kamerunicus Faust. (Coleoptera: Curculionidae) within oil palm plantations
}

\author{
Pollen load dan distribusi polen pada tubuh Elaeidobius kamerunicus \\ Faust. (Coleoptera: Curculionidae) pada tanaman kelapa sawit
}

\author{
Van Basten Tambunan ${ }^{1,2}$, Bandung Sahari ${ }^{2}$, Damayanti Buchori ${ }^{1,3}$, Purnama Hidayat $^{{ }^{*}}$ \\ ${ }^{1}$ Departemen Proteksi Tanaman, Fakultas Pertanian, Institut Pertanian Bogor \\ Jalan Kamper, Kampus IPB Dramaga, Bogor 16680 \\ ${ }^{2}$ PT Astra Agro Lestari, Tbk \\ Jalan Puloayang Raya Blok OR-1, Kawasan Industri Pulogadung, Jakarta 13930 \\ ${ }^{3}$ Center for Transdisciplinary and Sustainability Sciences (CTSS), IPB University \\ Jalan Raya Pajajaran No. 27, Bogor 16128
}

(diterima Desember 2019, disetujui Juli 2020)

\begin{abstract}
The African oil palm weevil, Elaeidobius kamerunicus Faust. is an effective pollinator of oil palm. Each individual palm produces exclusively male or female inflorescence so that the success of pollination depends on the ability of the pollinator to transfer pollen from male to female flowers. The objective of this research was to study the amount of pollen carried by E. kamerunicus between male and female inflorescences (pollen load) and the amount of pollen carried on each part of the weevil's body (pollen distribution). Fifty each of male and female E. kamerunicus individuals were collected from male and female flowers on trees in 3 locations: Siantar (North Sumatra), Dramaga (West Java), and Morowali (Central Sulawesi). Data on pollen load and pollen distribution on the weevil's body were analyzed using ImageJ software. Results show that E. kamerunicus individuals collected more pollen from male flowers than from female flowers. In addition, male insects carried more pollen on their bodies than female insects. Pollen distribution on weevil body parts was highest on the elytra, followed by the thorax, abdomen, legs, and head respectively.
\end{abstract}

Key words: body part, Elaeidobius kamerunicus, female, male, pollen load

\begin{abstract}
ABSTRAK
Kumbang penyerbuk asal Afrika, Elaeidobius kamerunicus Faust. merupakan kumbang yang efektif dalam membantu penyerbukan kelapa sawit. Keberhasilan polinasi bergantung pada kemampuan polinator dalam mentransfer polen dari bunga jantan ke bunga betina. Penelitian ini dilakukan untuk mempelajari jumlah polen yang dibawa oleh serangga penyerbuk dari bunga jantan ke bunga betina dan untuk mempelajari jumlah polen yang dibawa oleh setiap bagian tubuh kumbang. Masing-masing 50 E. kamerunicus jantan dan betina dari bunga jantan dan bunga betina dikoleksi dari 3 lokasi, yaitu Siantar (Sumatra Utara), Dramaga (Jawa Barat), dan Morowali (Sulawesi Tengah). Pollen load dan distribusi polen pada tubuh E. kamerunicus dihitung dengan menggunakan perangkat lunak ImageJ. Hasil penelitian ini menunjukkan bahwa E. kamerunicus yang dikoleksi dari bunga jantan membawa polen lebih banyak dibandingkan dengan E. kamerunicus yang dikoleksi dari bunga betina. Serangga jantan membawa polen lebih banyak dibandingkan dengan serangga betina. Elitra merupakan bagian tubuh yang membawa polen paling banyak diikuti oleh toraks, abdomen, tungkai, dan kepala.
\end{abstract}

Kata kunci: bagian tubuh, betina, Elaeidobius kamerunicus, jantan, pollen load

\footnotetext{
*Penulis korespondensi: Purnama Hidayat. Departemen Proteksi Tanaman, Fakultas Pertanian, Insttut Pertanian Bogor

Jalan Kamper, Kampus IPB Dramaga, Bogor 16680, Tel:Tel/Faks: 0251-8629364, Email: phidayat@apps.ipb.ac.id
} 


\section{INTRODUCTION}

Oil palm (Elaeis guineensis Jacq) is the highest yielding vegetable oil crop in the world (Hartley 1967; Tandon et al. 2001), and in cultivation, pollination is one of the most important factors affecting production yield. Pollination is required for the development of seeds and fruit (Mayer et al. 2011). E. guineensis is a monoecious plant, having both male and female flowers on the same tree, but co-located flowers are generally not able to pollinate each other. Flowers are receptive only to pollen from other oil palm individuals and so pollination must occur via wind dispersal or insects such as pollinator weevils (Hartley 1967; Sparnaaij 1969). Pollination by pollinator weevil is considered more effective than wind because insects can carry pollen to the inside of the flower (Syed 1979).

Elaeidobius kamerunicus Faust. is an effective pollinator weevil for oil palm. This African oil palm weevil was which introduced to Indonesia in 1982 and its presence has made an important contribution to increased fruit set of oil palm in Indonesia since then (Susanto et al. 2007). E. kamerunicus feeds, mates, and oviposits in the male inflorescences of oil palm (Syed 1979; Corley \& Tinker 2008). Pollination occurs when E. kamerunicus carrying pollen on their body travels out from the male inflorescences and visits receptive female inflorescences on other trees, drawn by the attractive effect of estragole. Estragole is a volatile compound released by female flowers that is similar to volatile compounds are released by male flowers (Susanto et al. 2007).

The amount of pollen carried by $E$. kamerunicus from male flowers in anthesis to receptive female flowers determines the success of oil palm pollination according to Pardede (1990). This finding has also been reported by Willmer \& Finlayson (2014), who noted that the success of pollination on vinca flowers was determined by the ability of bumblebees to collect and transfer pollen to the flower stigma. Body size was important because it influences effectiveness in collecting and transferring pollen. Large bumblebees were more effective pollinators than small bumblebees.

Investigation of the amount of pollen carried by E. kamerunicus and the distribution of pollen on each part of the weevil's body has not been widely reported previously. This study aims to add to our understanding of pollen load, pollen bodily distribution, and the influence of variation in pollinator body size on oil palm pollination.

\section{MATERIAL AND METHODS}

\section{The study site}

This study was carried out from December 2018 to July 2019. Insect samples were collected from oil palm plantations from 3 different locations in Indonesia (Figure 1).

\section{Collection E. kamerunicus sample}

Male and female E. kamerunicus were captured individually by hand from E. guineesis male and female inflorescences in anthesis, using tweezers $(N=200)$. While in the field, the insects sampled were grouped into 4 groups based on sex of insect and of source inflorescence ( $n=50$ in each group). Each individual weevil was placed in a flexible plastic $(2 \mathrm{~cm} \times 2 \mathrm{~cm})$, which was then folded to ensure the weevils could not move or fly away. The collected insects were transferred to the laboratory for preparation for pollen measurement.

\section{Pollen load from male vs female inflorescence}

Researchers followed the pollen counting method used by (Permana et al. 2017). Each weevil was placed into a microtube $(1.5 \mathrm{ml}$ size $)$ and washed using $100 \mu \mathrm{KOH} \mathrm{10 \%} \mathrm{(w/v)} \mathrm{as} \mathrm{a}$ solvent to disperse pollen and create a bonding effect between the pollen and solvent. Washing was performed by "pump-suck" methods with a small pipette, to wash all pollen grains, separate pollen clumps, and ensure flow of $\mathrm{KOH}$ to all of parts of the insect body. Then an additional 100-200 $\mu \mathrm{KOH}$ solvent was added, in order to decrease pollen density and distribute the pollen in a larger volume of liquid to facilitate examination. The $100-300 \mu 1 \mathrm{KOH}$ containing the washed pollen was transferred to a flat glass slide using a pipette.

\section{Pollen distribution on E. kamerunicus body parts}

E. kamerunicus body was examined in reference to 5 different parts: the head, thorax, abdomen, elytra, and legs. We measured the pollen distribution from each part for males and females 


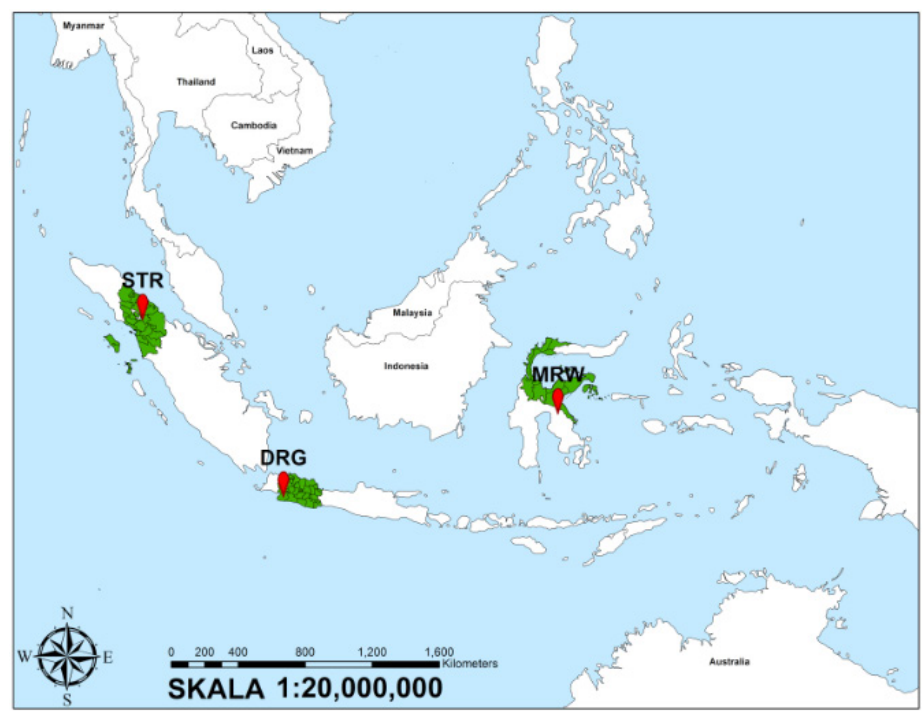

Figure 1. Localities sampled for Elaeidobius kamerunicus in Indonesia. STR: Siantar-North Sumatra; DRG: Dramaga-West Java; and MRW: Morowali-Central Sulawesi.

from male flowers, using the pollen counting method by Permana et al. (2017).

\section{Image analysis}

A Nikon SMZ 1500 stereomicroscope and Nikon Digital Sight DS-FI 1 camera were used to capture images of the pollen for each chamber with 1x magnification objective. NIS Element D 3.1® software was used to convert images into JPEG format. The data (20-30 images per individual $E$. kamerunicus insect collected) were placed into a digital folder for each insect, classified based on sex and inflorescences sources. ImageJ was used to process and analyze the captured image (Rashband 2001).

\section{Body size, body surface area measurement, and} counting pleural setae density

E. kamerunicus individuals, from all study site locations, were each observed using a stereo microscope, and body length and body width were measured using Dino Capture 2.0 software. Body surface area measurements and pleural setae density calculations were performed using a Leica M205C microscope with a Leica DFC450 digital camera processed through the LAS V.4.4.0 application (Build: 454) connected to a computer.

\section{Data analysis}

Pollen load count and body size measurement data were analyzed using one-way analysis of variance (ANOVA) and the means were separated by Duncan test at $95 \%$ confidence level using
Genstat 18th Edition. The relationship between E. kamerunicus body measurements on individual pollen load was analyzed by the Pearson correlation test.

\section{RESULT}

Pollen load carried by E. kamerunicus from male flowers varied by weevil sex, and study site location. The amount of pollen carried by male E. kamerunicus ranged from 238.8 to 1202.8 pollen grains, while the pollen load for female E. kamerunicus ranged from 208.3 to 348.9 pollen grains. With regard to study site location, results showed that for both male and female $E$. kamerunicus, weevils collected from the Siantar site had higher pollen loads than those collected from Dramaga and Morowali (Table 1).

Variations in pollen load according to study site locations were also observed for E. kamerunicus individuals collected from female inflorescences. E. kamerunicus collected from female flowers at the Siantar study site carried more pollen than those collected from female flowers in Dramaga and Morowali with the lowest pollen loads measured from Morowali.

In this study we also found that variation in pollen load in this study also correlated to variation in weevil body size across all 3 study site locations. E. kamerunicus individuals collected from Siantar, who as a group carried the highest pollen loads of the 3 locations, also had longer 
average body size than those of Dramaga and Morowali (Table 2). Likewise, the E. kamerunicus collected from Morowali, who carried the smallest pollen loads, had a smaller body size on average than those of Siantar and Dramaga. This shows a positive correlation between body size and pollen load. (Table 3).

In addition to variation in pollen load according to location and body size, in this study we also found that male E. kamerunicus carried a higher pollen load than females in all study site locations, whether gathered from male or female flowers. This is likely due to the larger average body surface area of male E. kamerunicus, which may allow them to carry more pollen than females (Figure 2). Furthermore, as shown in Figure 3, the male E. kamerunicus has pleural setae while the female does not. The presence of pleural setae helps male E. kamerunicus to carry more pollen.

Pleural setae can be found along the male $E$. kamerunicus elytra. A Pearson correlation test was conducted to understand the relationship between elytra surface area and pleural setae density, and the relationship of these measurements to the amount of pollen in the elytra. The results showed a significant positive correlation between the three variables (Table 4). The strongest correlation was found between elytra surface area and pleural setae density, with a coefficient value of 0.807 indicating a very strong relationship. In relation to pollen load, elytra surface area showed a strong relationship $(r=0.751)$, while pleural setae density showed a moderate relationship $(r=0.529)$ to the quantity of pollen measured in the elytra. The results of multiple correlation tests showed that elytra surface area and pleural setae density were both strongly related $(r=0.762)$ and had a very significant effect $(p$-value $<0.01)$ on the quantity of pollen in the elytra.

Pollen distribution on the body of $E$. kamerunicus collected from either male and female inflorescences showed a similar pattern for

Table 1. Pollen load of Elaeidobius kamerunicus indivisuals collected from male vs. female inflorescence $($ mean $\pm \mathrm{SD})$

\begin{tabular}{lcccc}
\hline \multirow{2}{*}{ Location } & \multicolumn{2}{c}{ Male inflorescence } & \multicolumn{2}{c}{ Female inflorescence } \\
\cline { 2 - 5 } & Weevil $\hat{O}$ & Weevil $\phi$ & Weevil $\hat{~}$ & Weevil + \\
\hline Siantar & $1202.8 \pm 104.8 \mathrm{c}$ & $348.9 \pm 34.2 \mathrm{~b}$ & $121.16 \pm 17.4 \mathrm{a}$ & $40.66 \pm 5.1 \mathrm{a}$ \\
Dramaga & $620.4 \pm 61.3 \mathrm{~b}$ & $298.1 \pm 23.3 \mathrm{~b}$ & $117.80 \pm 29.2 \mathrm{a}$ & $35.74 \pm 8.1 \mathrm{a}$ \\
Morowali & $238.8 \pm 21.6 \mathrm{a}$ & $208.3 \pm 15.2 \mathrm{a}$ & $95.76 \pm 18.3 \mathrm{a}$ & $26.88 \pm 6.8 \mathrm{a}$ \\
\hline
\end{tabular}

Number in the same column followed by the same letter are not significantly different from each other in Duncan's test at $95 \%$ confidence level $(\alpha=0.05)$.

Table 2. Variations in body length and width of Elaeidobius kamerunicus collected from several locations

\begin{tabular}{|c|c|c|c|c|c|c|}
\hline \multirow[b]{2}{*}{ Location } & \multicolumn{2}{|c|}{ Body length (mm) } & \multirow[b]{2}{*}{ p-value } & \multicolumn{2}{|c|}{ Body width (mm) } & \multirow[b]{2}{*}{ p-value } \\
\hline & $\begin{array}{l}\text { Weevil }{ }^{\lambda} \\
(\mathrm{n}=50)\end{array}$ & $\begin{array}{l}\text { Weevil } \text { + } \\
(\mathrm{n}=50)\end{array}$ & & $\begin{array}{l}\text { Weevil }{ }^{\lambda} \\
(\mathrm{n}=50)\end{array}$ & $\begin{array}{l}\text { Weevil } \text { } \\
(\mathrm{n}=50)\end{array}$ & \\
\hline Siantar & $3.439 \mathrm{~b}$ & $2.767 \mathrm{~b}$ & $<0.001$ & $1.464 \mathrm{~b}$ & $1.202 \mathrm{~b}$ & $<0.001$ \\
\hline Dramaga & $3.354 \mathrm{a}$ & $2.752 \mathrm{~b}$ & $<0.001$ & $1.432 \mathrm{a}$ & $1.195 \mathrm{ab}$ & $<0.001$ \\
\hline Morowali & $3.393 \mathrm{a}$ & $2.678 \mathrm{a}$ & $<0.001$ & $1.434 \mathrm{a}$ & $1.174 \mathrm{a}$ & $<0.001$ \\
\hline
\end{tabular}

Number in the same column followed by the same letter are not significantly different in Duncan's test at 95\% confidence level $(\alpha=0.05)$.

Table 3. Correlation of body size and amount of pollen on Elaeidobius kamerunicus (Pearson)

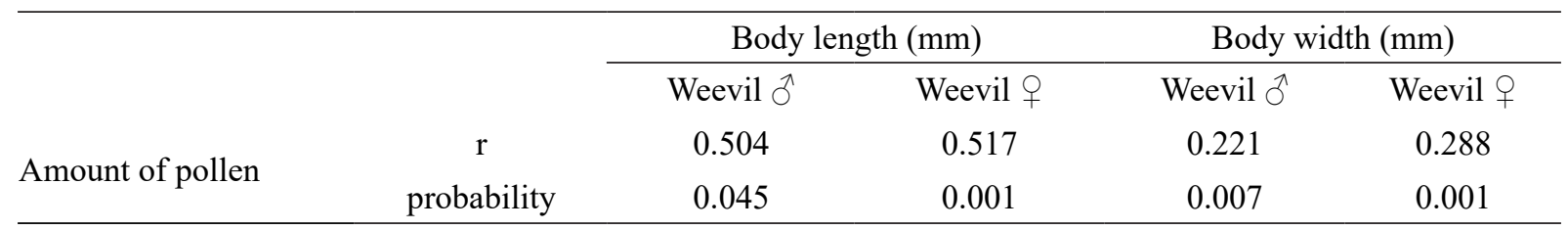

r: Pearson correlation; $*: \mathrm{p}<0.05=$ significant; $* *: \mathrm{p}<0.01=$ very significant. 


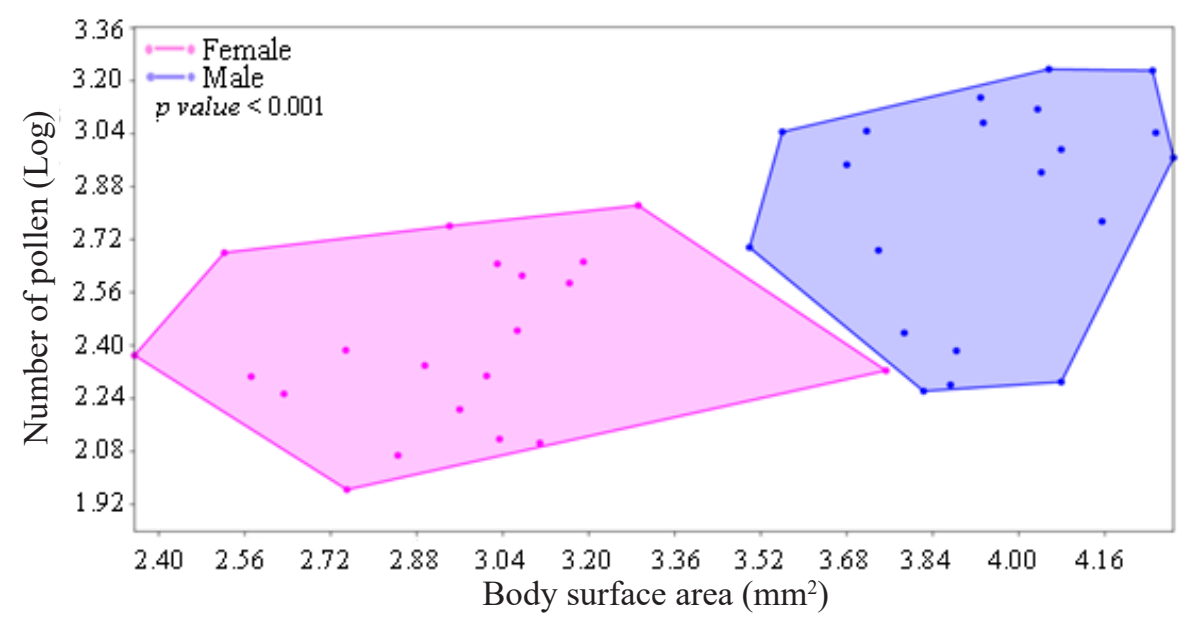

Figure 2. Correlation between number of pollen grains and body surface.

A

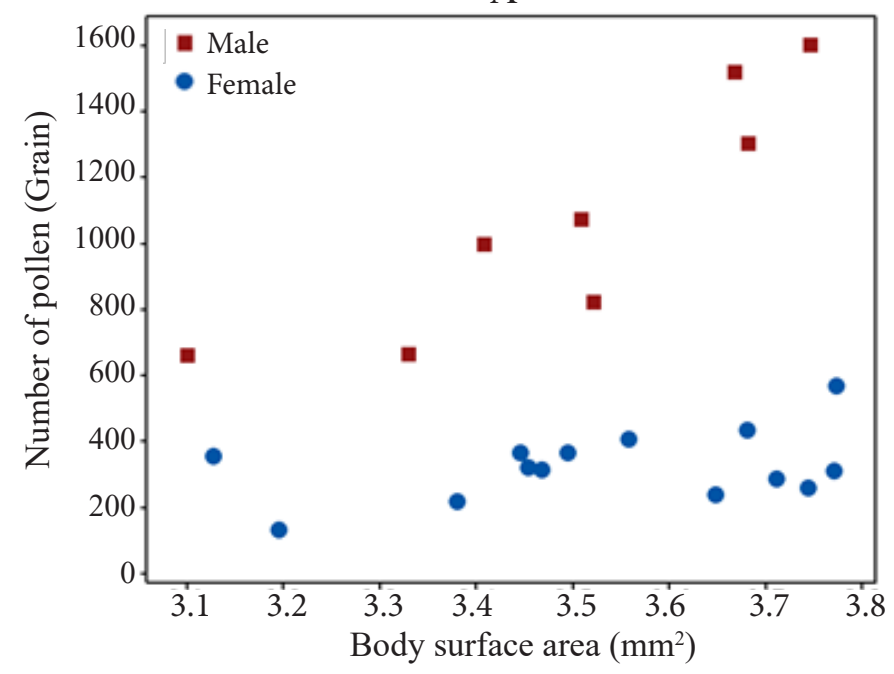

B
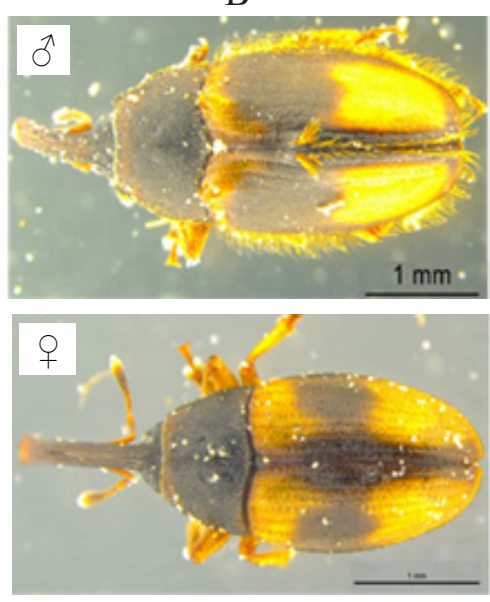

Figure 3. The quantity of pollen on Elaeidobius kamerunicus based on body surface area (A); The presence of pleural setae on E. kamerunicus (B).

Table 4. Correlation of elytra surface area, pleural setae density, and amount of pollen on elytra male Elaeidobius kamerunicus

\begin{tabular}{lcccc}
\hline & & $\begin{array}{c}\text { Elytra surface area } \\
\left(\mathrm{mm}^{2}\right)\end{array}$ & $\begin{array}{c}\text { Pleural setae } \\
\text { density } \\
\left(\text { per } \mathrm{mm}^{2}\right)\end{array}$ & $\begin{array}{c}\text { Elytra surface area \& } \\
\text { pleural setae density }\end{array}$ \\
\hline Pleural setae density & $\mathrm{r}$ & 0.807 & - & - \\
& probability & $0.000^{* * *}$ & - & 0.762 \\
Amount of pollen on & $\mathrm{r}$ & 0.751 & 0.529 & $0.005 * *$ \\
elytra (grain) & probability & $0.001^{* * *}$ & $0.043^{*}$ & \\
\hline
\end{tabular}

r: Pearson correlation. $*$ : $p<0,05=$ significant; $* *: p<0,01=$ very significant; $* * *: p<0,001=$ very significant.

both male and female insects. The greatest amount of pollen was found in the elytra, followed--in order from highest to lowest loads on the thorax, abdomen, legs, and head. (Figure 4).

The correlation coefficient of elytra, thorax, and abdomen surface area to the pollen loads measured for each body part ranges from 0.035 to 0.651 (Table 5). The highest correlation was found for the elytra of male E. kamerunicus (coefficient = 0.651) which is categorized as strongly related. This result tends to confirm the theory and results in Figure 2. 


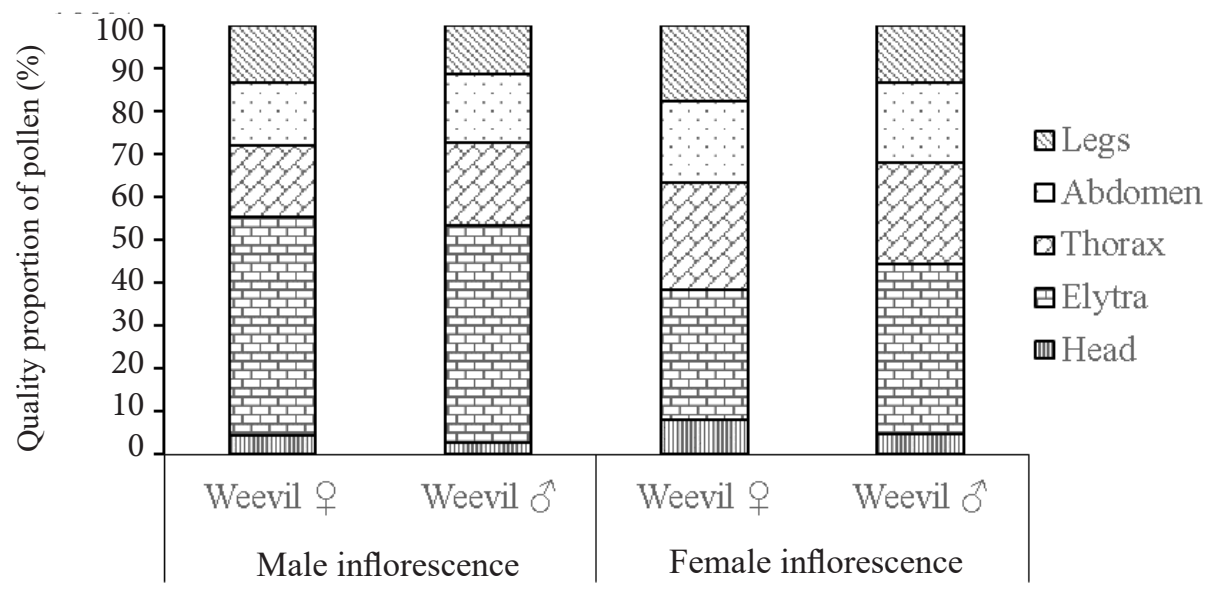

Figure 4. Proportion amount of pollen on body part of Elaeidobius kamerunicus.

Table 5. The body part surface area of Elaeidobius kamerunicus and its correlation with quantity of pollen

\begin{tabular}{|c|c|c|c|c|c|}
\hline \multirow[t]{2}{*}{ Body part } & \multicolumn{2}{|c|}{$\begin{array}{l}\text { Body surface area } \\
\qquad\left(\mathrm{mm}^{2}\right)\end{array}$} & \multirow[t]{2}{*}{ p-value } & \multicolumn{2}{|c|}{$\begin{array}{l}\text { Correlation between body surface area with } \\
\text { number of pollen grains (Pearson) }\end{array}$} \\
\hline & Female & Male & & Female & Male \\
\hline Head & $0.264 \mathrm{a}$ & $0.261 \mathrm{a}$ & 0.705 & -0.565 & -0.444 \\
\hline Legs & $0.464 \mathrm{~b}$ & $0.619 \mathrm{~b}$ & $<0.001$ & -0.445 & 0.232 \\
\hline Abdomen & $1.023 \mathrm{c}$ & $1.376 \mathrm{c}$ & $<0.001$ & 0.241 & 0.035 \\
\hline Thorax & $1.289 \mathrm{~d}$ & $1.723 \mathrm{~d}$ & $<0.001$ & 0.255 & 0.077 \\
\hline Elytra & $2.037 \mathrm{e}$ & $2.809 \mathrm{e}$ & $<0.001$ & 0.158 & 0.651 \\
\hline
\end{tabular}

Number in the same column followed by the same letter are not significantly different in Duncan's test at $95 \%$ confidence level $(\alpha=0.05)$.

\section{DISCUSSION}

The pollen load carried by E. kamerunicus collected from male flowers was greater than the amount of pollen carried by E. kamerunicus collected from female flowers. Specifically the pollen load of weevils collected from female flowers was only $17.62 \%$ of the load measured from those collected from male flowers. This might be due to motion causing pollen to be lost or fallen from the weevil body during flight from the male flowers, or because pollen has already been transferred to other female inflorescences prior to collection.

This study found differences in pollen load carried by weevils collected in Siantar, Dramaga, and Morowali, for both male and female weevils. These differences correlated to variation in $E$. kamerunicus body size found between the 3 sites. E. kamerunicus collected from Siantar carried the most pollen, and had larger average body size compared to weevils collected from the other sites.
E. kamerunicus collected from Morowali carried the least amount of pollen, and had the smallest body size. Similar results were found by Fikra (2015) who also reported a positive correlation between body size of E. kamerunicus and pollen load.

Body size in pollinating insects is an important factor, reported to affect effectiveness in pollination. Some studies, i.e. Agenginardi (2011) reported that E. kamerunicus individuals with larger body size tend to be more effective pollinators of palm oil. Furthermore, Willmer \& Finlayson (2014) concluded that the larger sized Bumblebee (Bombus spp.) carries and transfers more pollen and tends to be more active than insect pollinators of smaller average size.

This study also found differences in pollen load between male and female weevils. Male insects with pleural setae, and generally larger body surface area carried more pollen than female insects which lack pleural setae and have a smaller body surface area. This was true across 
all collection sites. Dhileepan (1992) provides a potential reason for differences in pollen load between the sexes, reporting that each pleural setae was capable of carrying at least 1 grain of pollen, so that presence of pleural setae can increase the pollen carried on the male elytra. In that study, body surface area and pleural setae had a positive correlation to the amount of pollen carried by $E$. kamerunicus.

The quantity of pollen carried respectively on the elytra, thorax, and abdomen of male and female E. kamerunicus positively correlated with body surface area (Benesty et al. 2009). Thus the greater the surface area of these body parts, the greater the quantity of pollen measured there. However, pollen load did not correlate to surface area for the head and legs of female $E$. kamerunicus. This echos results delivered by Syed (1979) and Agenginardi (2011) who stated that the elytra of E. kamerunicus carried the most pollen in comparison to other body parts.

\section{CONCLUSION}

The amount of pollen carried by E. kamerunicus from male inflorescences was greater than the amount of pollen carried by E. kamerunicus when visiting female inflorescences. Body sizes have a positive correlation with the amount of pollen carried by E. kamerunicus, and elytra was $E$. kamerunicus part which carried most of the pollen in comparison to other body parts. Difference in body size explains the differences in pollen load and pollinator effectives between variable groups: males with larger bodies carried more pollen than smaller bodies females; and weevils of both sexes were found to be larger in size and to carry more pollen in Siantar than in the other collection sites where weevils were smaller on average.

\section{REFERENCES}

Agenginardi EB. 2011. Jumlah Polen Kelapa Sawit dan Viabilitasnya pada Tubuh Kumbang Betina Elaeidobius kamerunicus Faust. Thesis. Bogor: Institut Pertanian Bogor.
Benesty J, Chen J, Huang Y, Cohen I. 2009. Pearson correlation coefficient. In: Benesty J, Kellermann W (Eds.), Noise Reduction in Speech Processing. Springer Topics in Signal Processing, Vol 2. pp. 37-40. Berlin, Heidelberg: Springer. doi: https:// doi.org/10.1007/978-3-642-00296-0_5.

Corley RHV, Tinker PB. 2008. The Oil Palm. New Jersey: John Wiley \& Sons.

Dhileepan K. 1992. Pollen carrying capacity, pollen load and pollen transferring ability of the oil palm pollinating weevil Elaeidobius kamerunicus in India. Oleagineux 47:55-61.

Fikra A. 2015. Morfometri Kumbang Penyerbuk Kelapa Sawit, Elaeidobius kamerunicus F. di Wilayah Desa Pandu Senjaya, Kota Waringin Barat, Kalimantan Tengah. Thesis. Bogor: Institut Pertanian Bogor.

Hartley CWS. 1967. The Oil Palm (Elaeis guineensis Jacq.). London: Longmans.

Mayer C, Adler L, Armbruster WS, Dafni A, Eardley C, Huang S-Q, Kevan PG, Ollerton J, Packer L, Ssymank A. 2011. Pollination ecology in the 21 st century: Key questions for future research. Journal of Pollination Ecology 3:8-23. doi: https://doi.org/10.26786/1920-7603(2011)1.

Pardede DB. 1990. Bioekologi Elaeidobius kamerunicus Faust (Coleoptera: Curculionidae) dalam Hubungan dengan Penyerbukan Kelapa Sawit. Dissertation. Bogor: Institut Pertanian Bogor.

Permana AD, Permana B, Sahari B, Putra RE, Kinasih I. 2017. Estimating numbers of oil palm (Elaeis guineensis) pollen grains using image analysis and processing. Journal of Oil Palm Research 29:311-317. doi: https://doi. org/10.21894/jopr.2017.2903.02.

Rashband W. 2001. Image J: Processing and analysis in Java, Version 1.25. Research Sciences Branch, National Institute of Mental Health, Bethesda, Maryland, USA. Available at: https://imagej.nih. gov/ij/ [accessed 21 December 2019].

Sparnaaij L. 1969. Oil palm (Elaeis guineensis Jacq.). In: Ferwerda FP, Wit F (Eds.), Outline of Perennial Crop Breeding in the Tropics. Miscelaneous Papers in Agriculture. pp. 339387. Wageningen: Wageningen University.

Susanto A, Purba RY, Prasetyo AE. 2007. Elaeidobius kamerunicus: Serangga Penyerbuk Kelapa Sawit. Seri Buku Saku 28. Medan: Pusat Penelitian Kelapa Sawit.

Syed R. 1979. Studies on oil palm polination by insects. Bulletin of Entomological Research 
69:213-224. doi: https://doi.org/10.1017/ S0007485300017673.

Tandon R, Manohara T, Nijalingappa B, Shivanna K. 2001. Pollination and pollen-pistil interaction in oil palm, Elaeis guineensis. Annals of Botany 87:831-838. doi: https://doi.org/10.1006/ anbo.2001.1421.
Willmer P, Finlayson K. 2014. Big bees do a better job: Intraspecific size variation influences pollination efectiveness. Journal of Pollination Ecology 14:244-254. doi: https://doi. org/10.26786/1920-7603(2014)22. 